\title{
IUCN GENERAL ASSEMBLY
}

REPRESENTATIVES of 43 nations attended the 9th General

Assembly and 10th Technical Meeting of the International Union for Conservation of Nature, held in Lucerne, Switzerland, from June 25th to July 2nd and presided over by Professor François Bourlière. The President of FPS, Lord Willingdon, attended several meetings, and the Society was represented by the Hon. Secretary, Mr Richard Fitter, and the Editor of ORYx. Other FPS Council members present were the Chairman, Mr Peter Scott, Lord Hurcomb, Sir Hugh Elliott, and Col. C. L. Boyle.

The discussions in the technical sessions had three main themes: the ecological impact of recreation and tourism on temperate environments; town and country planning problems, and the ecological changes caused by introduced animals and plants, in the last of which Mr Fitter read a paper on introductions in Europe. This session had one of the liveliest discussions of the week, with American and Russian delegates and others from large countries ranged in favour of introductions, and the island dwellers, like the British, and those from small countries like Holland, more concerned with the dangers of such introductions as the mink, coypu and grey squirrel.

At the final session the new President, Dr Harold J. Coolidge of the USA, took over from Professor Boulière, and gave a stimulating address outlining a forward-looking programme for his presidency. Among the three new Vice-Presidents appointed was Dr F. Fraser Darling, a member of the FPS Council, who is also one of the new members of the IUCN Executive Board, along with Mr Russell E. Train of the USA, President of the Conservation Foundation. Professor Bourlière takes over the Chairmanship of the Commission on Ecology in place of the late Dr E. H. Graham, Profesosr J.-P. Harroy follows Dr Coolidge as Chairman of the National Parks Commission, Mr E. J. H. Berwick suoceeds Sir Hugh Elliott as Secretary-General, and Sir Hugh becomes Special Duty Officer in London. Mr Berwick has just retired as Director of Agriculture in Sabah (North Borneo).

The next General Assembly of IUCN is to be held in New Delhi in 1969 .

\section{Dr. Edward H. Graham, 1902-1966 \\ By F. Fraser Darling}

THE sudden death of Edward Graham on May 16th has been a profound shock to his many friends in five continents, and to the numerous organisations of national and international character concerned with conservation to which he gave so freely of his effort and advice. He was chairman of the Commission on Ecology of IUCN, and had accepted the onerous duty of president of the Union for the coming critical three years. He was also deputy-convener of the conservation section of the International Biological Programme. 